シャップ半島と地質条件が同じにもかかわらず，全 く別の，V字谷に刻まれた壮年期的山相を是する.

両山地の海抜高度および侵蝕基準面に対する比高に も大差がないから，北部の被周氷河作用地域の原地
形がすでに老年期的であつたということはできない．

この報告にあつたつて，東京大学・東京都立大学・ボン大学の 各地理学教窒の方々に咸謝いたします。また文部省科学研究費の 一部を使用したことを記して戚詏いたします。(1960 年 8 月 15 日 受理)

\title{
PERIGLAZIALE ERSCHEINUNGEN IN NORD-HOKKAIDO
}

\section{Hideo SUZUKI}

Die Hügellandschaft in Nord-Hokkaido ist bisher als Beispiel eines späteren Stadiums der normalen Erosion betrachtet worden. Bei der genaueren Untersuchung hat der Verfasser festgestellt, dass sie durch die periglaziale Verflachung entstanden ist. Die Beweise dafür sind Dellen, Blockströme, fossile Strukturböden und ein Eiskeil ; letzterer ist allerdings noch fraglich. Daneben wurden auch rezente Solifluktion (in $168 \mathrm{~m}$ ü. M.) und Nivation (in $150 \mathrm{~m}$ ü. M.) gefunden.

Für das Zustandekommen der vorliegenden Arbeit ist der Verfasser Herrn Prof. Dr. C. Troll und anderen Damen und Herren im Geographischen Institut der Universität Bonn zu Dank verpflichtet.

\section{〔短報〕西津軽地方に利ける海岸段丘面上の砂丘について}

\section{大倉陽子}

\section{まえがき}

箐者はこの数年来，段丘面の縱断面形および段丘 堆積物の状態と，段丘面形成中における地盤運動と の関係を知るために，西津軽地方の海岸段丘の調査 をおこなつてきた。 その際に，場所によつては，段 丘面上に砂丘があつて，段止面や段丘崖の表面形態 老著しく修飾していることに気がついた。おが国の
海岸砂丘についてはすでに多くの研究があり，最近 はとくに台地または段丘面上に分布する砂丘につい てもかなり注意されており1，大規模な砂丘にみえ る地形も，古い砂層からできた台地の上に薄く砂を 堆積していることが多く，砂丘の厚さは意外に薄い むのであることが指摘されている2． 鰺が沢以北に ある津軽砂丘についても, 海底堆積面の上昇して生

1）たとえば.

a 、小笠原義勝：(1951) 日本の風蝕地形に関する若干の考察——下北半島および関東南部を中心として— 資源研畺報，19/21，110 118.

b. 大矢雅彦・市瀬由自：(1958) 下北半島の海岸砂丘第 1 報. 資源研彙報，46/47，5～12.

c . 大矢雅彦・市瀬由自・和島誠一 (1959)：志布志湾岸の平野地形第1 報——海岸砂丘を中心として一。 資源研巢報，49，39〜50.

d. 吉川虎雄・斎藤光格 (1954）：房総半島千倉港付近の海岸ならびに海底の地形. 東大地理学研究，3，40 $\sim 50$.

e. 坂口 辢 (1959)：北海道の新しい時代の地颉運動. 地理評，32，401 431.

f. 中野尊正 (1953) : 平野. 目本地理新大系 I, 自然, $46 \sim 47,73$.

2) a. 中野尊正 : 前揭 1) f. p.53.

b. 山本䓅毅（1959）：海岸地下水，とくに砂州の地下水について. 地理評，32，579～594. 
じた海岸平野上にのるもの ${ }^{3)}$ であることがすでにの ベられている，しかし，筆者か調査した地域（青森 県西津軽郡の海岸地方，鯪が沢から深浦をへて沢辺 に至る地域）については，また具体的な記載をみな いようである，そこで，海岸段丘地形に関する詳し い報告は別の機会にゆずり，以下には，本地域の砂 丘の分布とその形成条件，形成過程および砂丘によ る表面形態の変化などについて簡単な記載と考察を 試みたい。な抢，御指導いただいた東京教育大三野 教授，町田助教授に感謝申し上げる.

\section{砂丘の分布と形状}

西津軽地方には模式的な海岸段丘地形が発達して
おり，少なくとも5 段以上の段丘面が分布している。 筆者は，先にのべた目的の関係上，段丘面の原形が よく保存されていると思われる，旧汀線高度約 80〜 $100 \mathrm{~m}$ の段丘を第 1 段乓とよび4)，それ以下第 4 段 丘までを区別した 第 2 段丘面以下である。第 2 段丘面は本地域を通し てもつとも巾が広く，また普遍的に分布して扮り， 旧汀線高度は 50 60 $\mathrm{m}$ である. 第 3 段斥面は大戸 瀬崎付近から立待崎にかけて分布し，かなり巾は狭 く，旧汀線高度は $30 \sim 40 \mathrm{~m}$ である. 第 4 段丘面は深 浦以北に分布し，旧汀線高度は 5 〜 $10 \mathrm{~m}$ である.

これらの段丘面の上にのる砂丘の分有を調查する

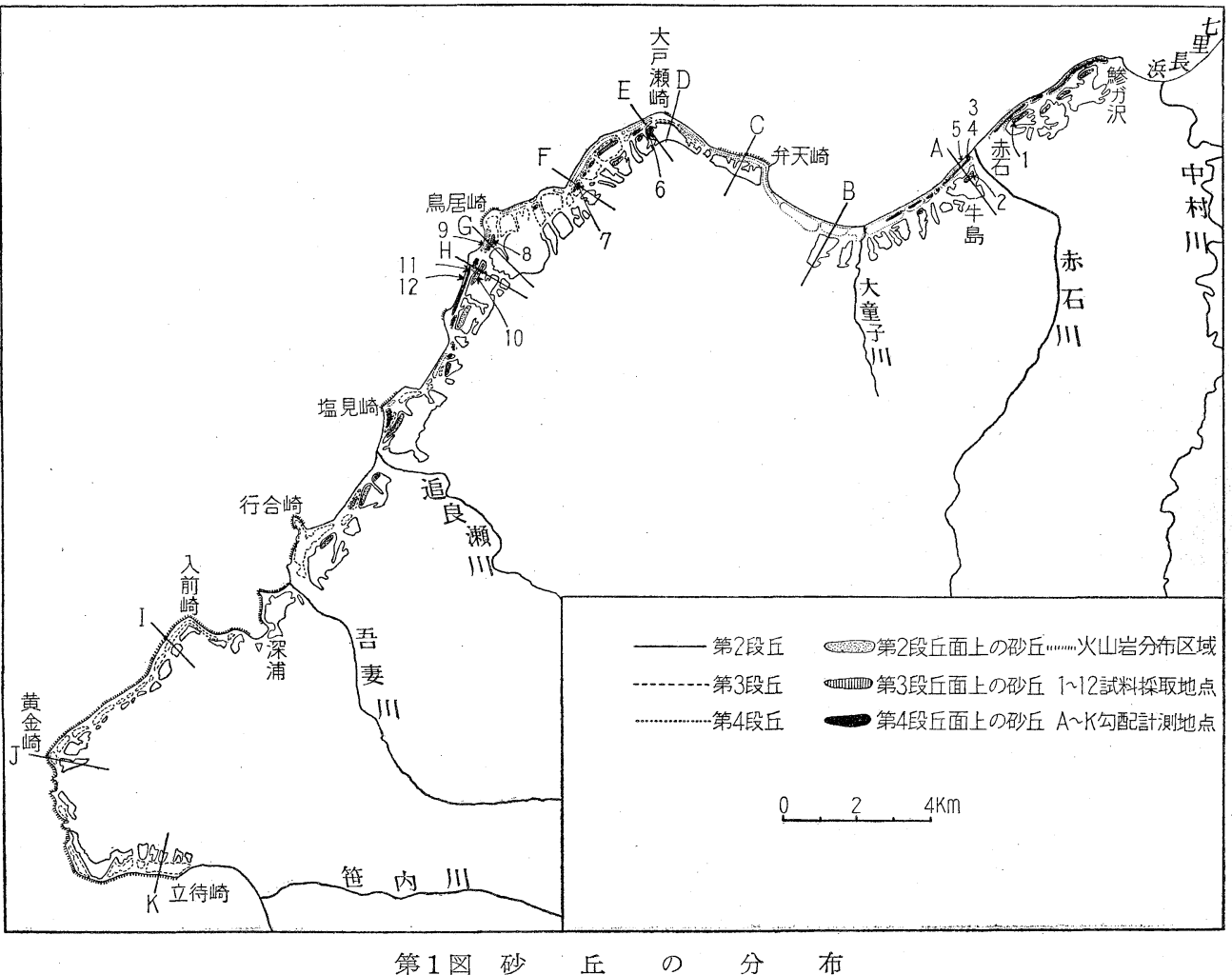

3）渡辺 光 (1956) : 海岸地形. 新地理学講座, 自然地理 I，308 309.

4）これ以上に少なくとも 1 段の段丘面がある.

5）大倉陽子 (1960)：海岸段丘面の形成過程に関する地形学的研究一一西津軽地方において一（未公表）. 段丘の対比，高度，分布についてはこの論文にのべてある.後にまとめて公表の予定であるので，ここに はかんたにのべるだけにする。 
と,符 1 図のようになる。その分布は,大体において 海岸線の方向と関係しており, 北東〜南西方向の海 岸線をもつ場所(鯵が沢〜大童子川付近, 大戸瀬崎〜 行合崎付近)たシけに限られている。しかし,深浦以南 ではどの方向の場所に山砂丘はまつたく存在しない。

砂丘の形状についてみると，新しい段丘にのるも のは非常に明䐲であるが（写真 1 ），古い段丘にの るむのは不朋瞭で，砂丘の勾配もゆるい（写真 2 ,

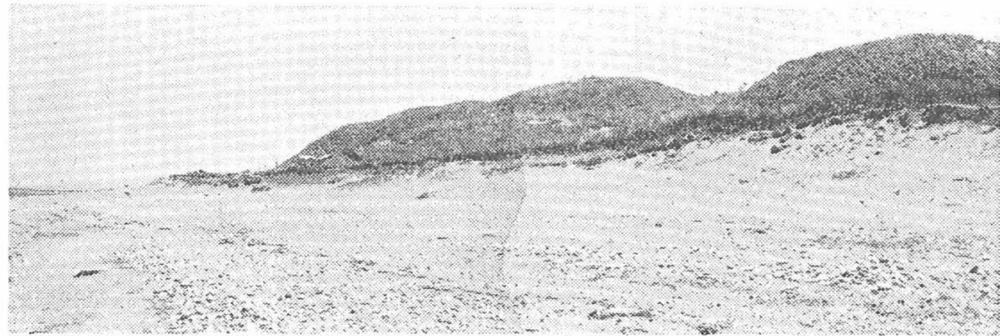

写真 1 牛島付近の第 4 段丘面上の新しい砂丘

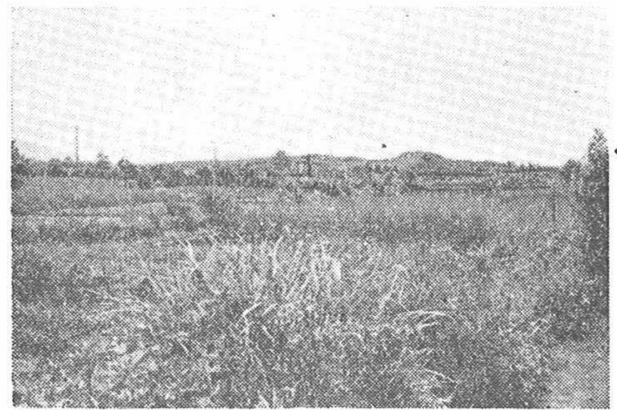

世酹丘(ここでは形息が非

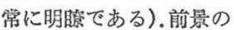
可坦な即が笏 2 段丘面

写真 2 赤石付近の第 2 段丘面とその上の砂丘
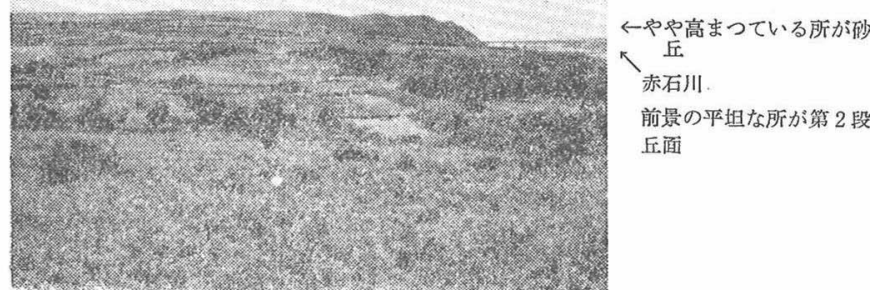
赤石川 前最の平坦な所方第 2 殷 丘面

写真 3 牛島付近の節 2 段丘面とその上の砂丘

をもつことが多い

\section{眇丘の分布と風向との関係}

砂丘の形成に当つては，砂を動かす のに十分な強さをもつ 卓越風との関係が重要であるといわれ ている7. そこで，本地域の砂丘の分 布が一定方向の海岸線と関係している ことは，卓越風との関係によるもので はないかと考えて，風に関する資料を みると，第 1 表のようになる8

第1表は深浦に抢ける風の状態であ る.この值が，一応本地域全体を代表 するものとすると，年間を通じての卓 越風向は SW であるが，この方向の 風㤝打もに陸地から吹き出すものであ る. それに対し，冬の卓越風向は打も にWNW で，海から陸へ向う風であ

6) Worcester, P. G. (1948) : A Textbook of Geomorphology. p. 222.

7) Thornbury, W. D. (1954): Principles of Geomorphology. p. 303.

8）本邦海岸気候表（1948），水路局書誌（701）. 
り，砂丘の形成に関係するものと思 われる. そして，冬には他の季節に おけるよりも平均風速が大きく，暴 風日数孔多い, このような冬の卓越 風向に対する本地域の海岸の露出の 状態をみると， 2 つの部分にわける ことができる，すなわち，NE〜SW 方向の海岸線を多つ場所は，冬の卓 越風に直面するが，それ以外の方向

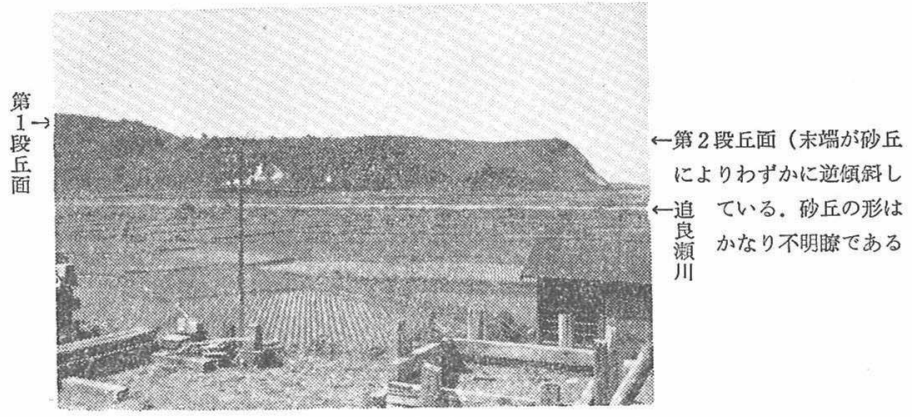

写真 4 迫良瀬川南方の管 2 段丘面とその上の砂丘

第 1 表 深 浦 の 風 の 状態

\begin{tabular}{|c|c|c|c|c|c|c|c|c|c|c|c|c|c|c|c|}
\hline 月 & 1 & 2 & 3 & 4 & 5 & 6 & 7 & 8 & 9 & 10 & 11 & 12 & 年 & & 繌計年次 \\
\hline 最多風向 & WNW & WNW & SW & SW & SW & SW & SW & WSW & $\mathrm{SE}$ & SW & W V & WNW & SW & \multirow{3}{*}{ 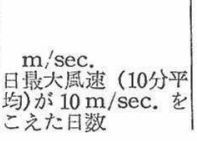 } & $1940-1945$ \\
\hline 平均風速 & 5.2 & 5.1 & 4.5 & 4.6 & 3.6 & 2.6 & 2.5 & 2.1 & 2.6 & 3.2 & 4.4 & 5.2 & 3.8 & & "I \\
\hline 悬栭日数 & 14.8 & 12.3 & 12.3 & 12.7 & 8.3 & 2.5 & 1.7 & 1.0 & 2.8 & 4.7 & 11.3 & 15.7 & 100.2 & & "I \\
\hline
\end{tabular}

の海岸線をもつ場所は，そのかげに当る、このよう な海岸線の方向の差異による風のうけ方の差異は， 帮際にきわめて眀瞭に観察でさる。たとえば，3月 下旬の北西風の強い日の推察によると，大戸瀬崎か ら西側（海岸線の方向は NE〜SW）では非常に風 が強く積雪も少ない。また海岸付近の樹木は，風下 の方向に著しくたわんでいる。一方，大戸瀬崎から 東側 (海岸線方向は NW〜SE) 厄゙は，風は非常に おだやかで積雪が多いことが認められた。

結局，本地域の砂丘の分布は，上述のような冬の 卓越風に対する露出の状態に支配され，それに面面 する NE〜SW 方向の海岸線の地域だけに限られて いる.

\section{砂丘の分布之砂の供給源己の関係}

第 1 困をみると，入前岬〜黄金崎間では，冬の卓 越風に直面しているにもかかわらず，砂丘は全く存 在しない,そこて，砂丘の形成にとつては，風向以 外の因子，とくに砂の供給地域の大小9かが問題にな つてくる. 砂丘砂の供給源は海岸の beach deposits
であると思われるので，全地域にわたつて現在の海 岸線付近の状態を調查した.

大部分の場所では, 海岸線付近に beach が発達し ている. その堆積物の状態は所によつて異なり，と くに流大する川の河口付近には大きな boulder が存 在するが，一般には pebble や cobble をまじえた中 〜粗粒の砂からなつている.このような海岸を一応 砂浜海岸とよぶ.これに対して，ほとんど beach を もたない海岸がある（たとえば弁天崎西方，大前岬 ～立待崎閒). すなわち，海面とすれすれの平坦な， 巾 $100 \mathrm{~m}$ 以下の bench が発達していて，その表面に は全然堆樍物はない, benchと海蝕崖との間に狭い beach があることもあるが，巾は10 m 以下にすぎ ずまたその堆積物は大部分 boulder からなり，わ ずかの cobble や pebble をまじえているが，砂はほ とんど存在しない.この種の海岸を一応岩石海岸と よぶ.これら2種の海岸の状態は, 海岸付近を構成 する岩石の性質と密接に関係している.すなおち， 砂浜海岸は，本地域の大部分にみられる新第三紀の

9）前揭 7) 
堆積岩からなる場所に分布し，岩石海宸の分布は火 山岩（おもに安山岩，一部は流紋岩）からなる場所 (第1図) $)^{100} に$ 限られている.

新第三系の岩石は，比較的くずれ易く，砂を生産 しやすいのに対し，本地域の火山岩はきわめて緻密 で固く，また基盤から岩塊へという不連続的風化 ${ }^{11)}$ をおこなうために砂を生産しにくいのであろう。こ のような構成岩石の差異が，砂の供給の仕方と beach の形成に関係し，ひいては砂丘の形成に影響し て，冬の卓越風に直面する地域の中でも，砂を生産 しにくい火山岩からなる場所には砂丘が形成されな かつたものと考える122.

な打，砂丘の生成が基盤岩石の性質と関係してい る一例として，房総半島の千倉付近の例がある。こ の地域の海岸段丘については，すでに詳しく報告さ れ，川尻川以北の新しい砂層からなる段丘面の末端 には砂丘がのつているが，川尻川以南の固結した第 三系をきる段丘面上には，段丘堆積層も砂丘も存在 せず，現在の海岸にも beach がないことがのべら れている(3)，その形状は第 2 図のようである ${ }^{14)}$ 。こ のように，千倉付近に抢いても，基盤岩石の差異が
砂丘の存否に関係し，砂丘砂の供給源として，未㠜 固な砂層の存在が大きな意味をもつている.

\section{砂丘砂の粒度組成}

つきに，砂丘砂の粒度組成を調查した。試料採取 地点は第 1 図にあらわしてある。乾燥させた試料 20 gを 皇 scale にしたがつてふるいわけをおこない， 重量比を求め，粒径中央值 $(\mathrm{Md} \phi)$ 打よび分級度 (PD $\phi)$ を求めた（第 2 表)。な抢，比較のために， 現海浜の砂についても 3 か所で試料をとり，同様な 処理をした.

砂丘砂は, 大体 $0.25 \sim 1 \mathrm{~mm}$ 程度の砂からなり. 非常に sorting がよい. 砂丘砂と現在の beach の砂 とくらべると，beach の砂の方が一般にや〉粗粒で， $1 \mathrm{~mm}$ 以上の粗い砂の割合が多く，砂丘砂の大部分 を占めていた $1 \mathrm{~mm}$ 以下の粒は少ないことが多い． このことは，beach の砂の中の細粒のもだけが風で 運搬されて砂丘砂となるのであるが，その際の風に よつて運搬される粒径の限界を瞕示しているものと 解釈される.

また，古い（高い）段丘面上にある砂丘の砂は， 新しい段丘面上のものよりも細粒のものが多く，し たがつて Md $\phi$ も多少小さくな つている傾向がある。このよう な傾向は，前記の千倉付近の場 合においても同様である.これ は，各砂丘の形成期における形 成条件（たとえば風の強さ）が 異なるためか，または，形成後

10）青森県庁（1957）：青森県下地域別地質調查報告書を主とし，細部については筆者の観察結果を加えてあ る.

11）小出 博（1952）：広用地質一一岩石の風化と森林の立地- - p. 64.

12）な抢，深浦以南の火山岩地域の段丘面上には，数か所に比高 $5 \mathrm{~m}$ 前後の高まりがある。しかし，これは 砂丘ではなく，基盤岩石からなつて抢り，海蝕からとりのこされた侵蝕遺物である。このような侵蝕遺物 は新三系の分布地域にはない。このことは，両種の岩石の侵蝕に対する抵抗性の差異を反映しているもの であろう。

13）吉川虎雄・斎藤光格：前揭 1） d .

14）川尻川以北（千倉）と以南（平磯）の 2 か所に打いて，段丘面と大体直交する方向に測量した実測図か ら作つた縦断面図である。 
第 2 表砂丘および海浜砂の粒度組成

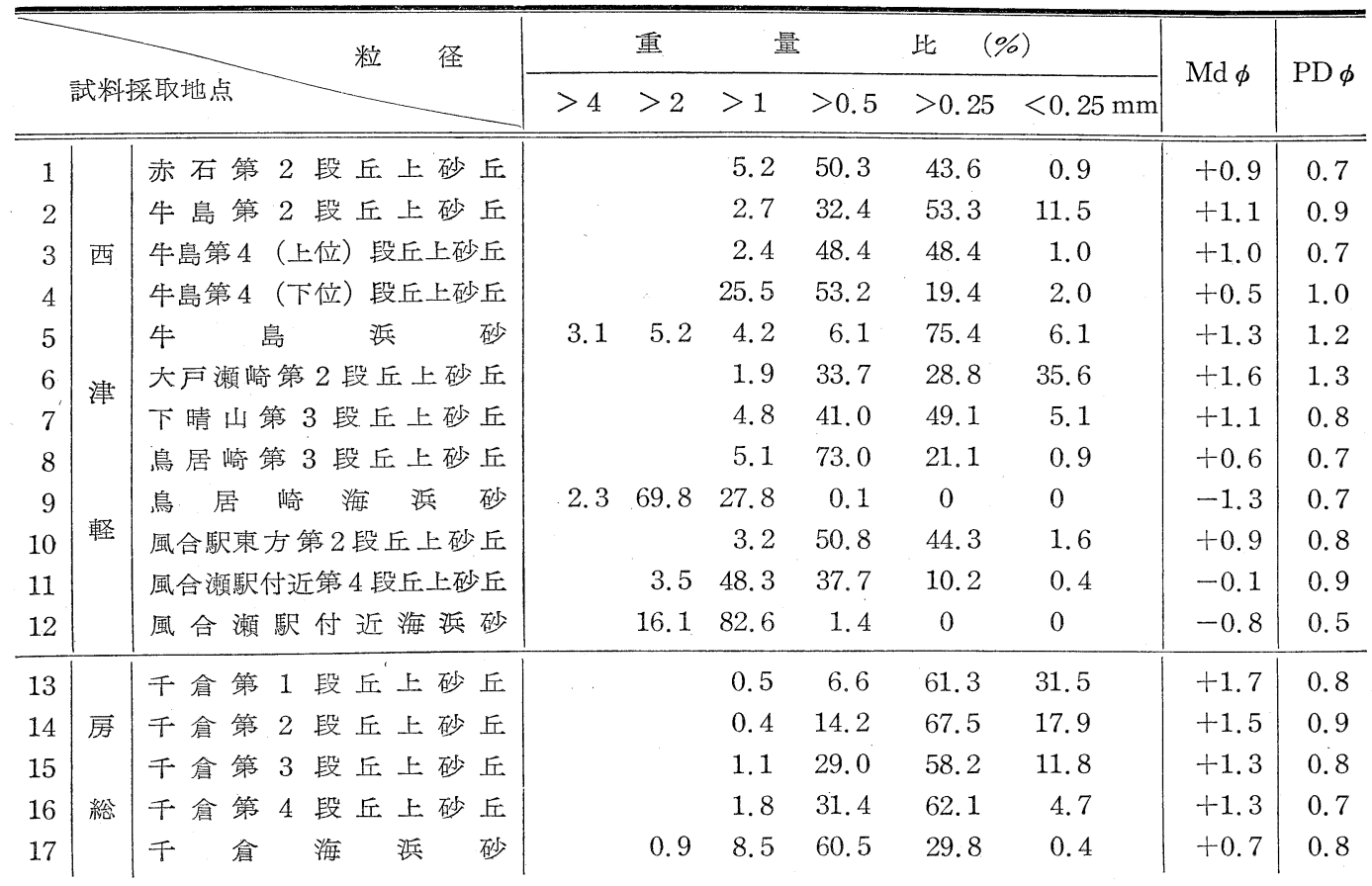

の風化によるものかのどちらかであろう，目下，そ れを確めるための資料をもたないが，1）西津軽で も千倉でも同じ傾向をもつこと，2）古い砂丘砂の カが細粒であるということが，先にのべた，古い砂 丘ほど形態が不明膫であるという事奏と対庥してい ること，などの点から，一応形成後の風化によるも のと解釈しておく、すなわち，形成後の時閒が長い ほど，風化，侵蝕作用が著しく働いて砂は細粒とな り，砂丘の形態も不明瞭になり，つい消失するも のと考えたい.

\section{砂丘の形成過程扎よび砂丘による海岸段丘地形の 二次的変形}

つぎに砂丘の形成過程を考えてみたい，段丘面に 砂からなる小規模な高まりが，つねに砂丘であると は限らない。たとえば，嵐の時に形成された過去の beach ridge に当るものであつたり ${ }^{15)}$ あるいは過 去の off-shore bar であるという例 ${ }^{16)}$ もある. しか し，本地域の場合においては，1）これらの高まり がつねに段丘面の未端に分布し，しかも崖と平行し ていること，2）この高まりを作る砂は beach の砂 よりも細粒であること，3）段丘崖を作る基盤岩石 を砂が抢抢つていること，4）分布が海岸線の方向 と一定の関係をもつていること，および，とくに重 要な点として 5）この高まりを作る砂は，写真 5 に あらわれているように，段丘堆積物上部にできた厚 さ 60〜 $80 \mathrm{~cm}$ に達する $\mathrm{A}$ 層上にのつていること，な どの諸点から海面下で形成されたものではなく，段 丘面が陸化後かなりの時間がたつてから，砂が崖下

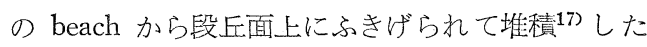
海岸砂丘であると判断した。すなわち，ある段丘面

15) Gilbert, G. K. (1885) : The Topographical Features of Lake Shore.

16) Miller, D. J. (1953) : Late Cenozoic Marine Glacial Sediments and Marine Terraces of Middleton Island, Alaska. Jour. Geol., 61, 17 40.

17) Lobeck, A. K. (1939) : Geomorphology. p. 385. 


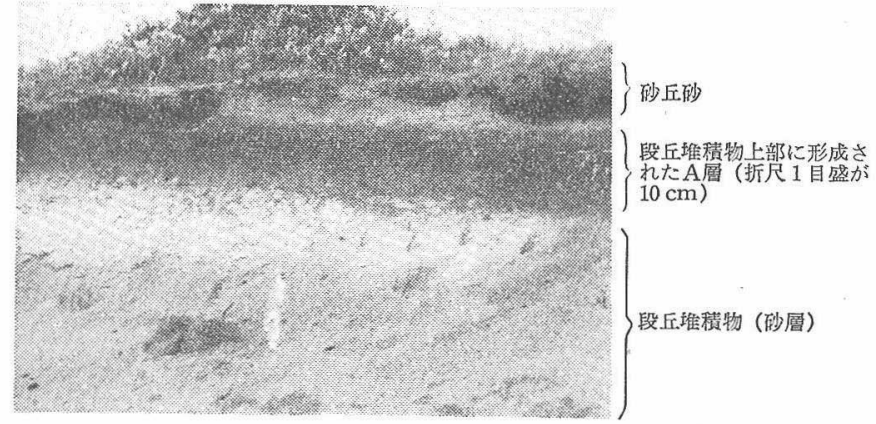

写真 5 赤石北方の第 2 段丘露頭

が陸化するような隆起運動の後に，比較的实定した 期間があつて，陸化した段丘面は新しい海面に関連 した湤蝕作用によつて後退する，同時に海面下の海 蝕面は次第に広くなり，また海蝕崖下にはかなりの 規模の beach ができ，その beach の砂が扣もに冬 の卓越風によつて崖上にふきあげられ，段丘面末端 に，陸化後に形成された厚いA層をおおつて砂丘と 第3表 段丘崖の勾配

\begin{tabular}{|c|c|c|c|c|c|c|}
\hline \multirow{2}{*}{$\begin{array}{l}\text { 場1) } \\
\text { 所 }\end{array}$} & \multicolumn{2}{|c|}{ 第 2 段丘崖 } & \multicolumn{2}{|c|}{ 第 3 段丘崖 } & \multirow{2}{*}{ 海岸線方向 } & \multirow{2}{*}{$\begin{array}{l}\text { 砂有 } \\
\text { 兵無 } \\
\text { の }\end{array}$} \\
\hline & 勾配 & (崖高) & 勾配 & (崖高) & & \\
\hline A & $19^{\circ}$ & $(45 \mathrm{~m})$ & & & $\mathrm{NE} \sim \mathrm{SW}$ & あり \\
\hline B & 45 & $(50)$ & & & $\mathrm{NW} \sim \mathrm{S} \mathrm{E}^{*}$ & なし \\
\hline $\mathrm{C}$ & 44 & $(51$ & & & $N W \sim S E *$ & なし \\
\hline $\mathrm{D}$ & 33 & $(9$ & $48^{\circ}$ & $(24 \mathrm{~m})$ & $\mathrm{NW} \sim \mathrm{S} \mathrm{E}^{*}$ & なし \\
\hline $\mathrm{E}$ & & & 28 & $(26)$ & $\mathrm{NE} \sim \mathrm{SW}$ & あり \\
\hline$F$ & 8 & (11 & 21 & $(24)$ & $\mathrm{NE} \sim \mathrm{SW}$ & あり \\
\hline G & & & 23 & $(28)$ & $\mathrm{NE} \sim \mathrm{SW}$ & あり \\
\hline $\mathrm{H}$ & 10 & $(6$ & 20 & $(20)$ & $N E \sim S W$ & あり \\
\hline I & 18 & $(12$ & & & $\mathrm{NE} \sim \mathrm{SW}$ & なし \\
\hline $\mathrm{J}$ & 17 & $(21$ & 35 & $(13)$ & NS & なし \\
\hline K & 21 & (18 & 35 & $(10)$ & $\mathrm{EW} *$ & なし \\
\hline
\end{tabular}

1) 場所は第 1 図参照.

2）第 2 段丘面の前面の崖（第 2 段丘とその下位の段丘と去境す

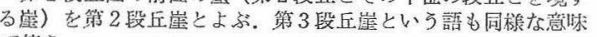
で使う。

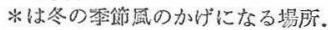

して堆䅡されたものであろう。

このようにして形成された砂丘は， 段丘の表面形態にかなりの恋化を与え ている、すなわち，段丘面は海側に向 つてゆるやかに傾いているのが常であ るが，砂丘は，面の末端に不規則な高 まりを作り，逆傾斜を生じている。 た段丘崖の勾配も砂丘の有無により著 しく異なつている。第 3 表は，第 1 図 の $\mathrm{A} \sim \mathrm{K} の 12$ 加所におらける段丘崖の勾配である18). これによると，崖高がほとんど同じ場合でも199，冬 の卓越風に直面する側の段丘崖は，砂丘砂でおおお れて，本来の段丘崖がかくされ. 平滑なゆるい斜面 となつているが，風かげに当る場所では砂丘がない ので，段丘崖は本来の形態を保持し，基盤が露出す る急崖となつていて，両者の対照はきわめて著しい （たとえば，A地点の第 2 段丘崖の勾配は，ほとん ど同じ崖高をもつ $\mathrm{B} ， \mathrm{C}$ 地点のそれよりはるかにゆ るやかである。なた，D地点の第 3 段丘崖と E， F， $\mathrm{G} ， \mathrm{H}$ 各地点のそれとの間にも同様な関係があ る).一方, 深浦以南の火山岩分布地域では，前記 のように砂丘が形成されていないので，どの方向に 面する段丘筐む大体似た勾配をむつている。

海:岸段丘の縱断面形の地形分析から，段丘の形成 に関係した地盤運動の性質が推定できるといわれて いるが20)，その際には，このような本来の段丘地形 形成後の二次的変化について十分斨味しておく必要 があると思われる。

なお，賐が沢から北臬には，七里長浜を始とする 海抜高度 $60 \mathrm{~m}$ 前後に達する広大な砂丘がつづいて

18）各場所で，旧汀線に大体直交する方向にとり，平板測量により作製した $1 / 3000$ の夹測図から段丘崖の勾 配を求めたものである。测量にさいして御助力いただいた木畑昌長，太田勇，白井哲之，結城邦子その他 の方々に愿く感謝する。

19）また，刓成特代が異なると，崖の傾斜は異なるから，以下では同時代でほぼ同高の崖についての比較を おこなう。

20）渡辺 光 (1939）：海岸段丘の縱断プロフアイルの傾斜について。地理評, 15，461〜 463. 
いる、これは，前述のように全部が砂丘ではなく ${ }^{21) ， ~}$ 砂丘砂の下に砂礫層，さらにその下に第三乔が存在 することが観察できる．まだ詳しく調査をしていな いが，これらの地形は，砂丘の規模こそ大きいが， 本質的には，鯵が沢から南の今回の研究地域と同様 に，海成平坦面上に砂丘がのつた地形であると考え られる，すなわち，七里長浜付近では，砂丘の形成 条件にめぐまれていたので，砂丘はその下の台地を ほとんどかくし，ふつうに砂丘として認定される地
形を作つており，一方，本研究地域では砂丘の規模 が小さいので，ふつうには海岸段丘として認定され る地形をあらわしているのである.このように鮭が 沢以北と以南の両地域の表面形態は全く異なつてい るが，それは，地形形成営力の本質的な差異による ものではなく，むしろ種々の営力の強さの差異に基 くものではないかと解釈する.これらの点について は，今後の研究にまちたい:(1960年 8 月 29 日受理)

\section{SAND DUNES SITUATED ON THE MARINE TERRACES IN NISHI-TSUGARU REGION, AOMORI PREFECTURE}

\section{Yōko ŌKURA}

In Nishi-Tsugaru region along the coast of the Japan Sea, there develop typical marine terraces which are partly covered by sand dunes. The author surveyed the disribution, geomorphic features and composition of the sand dunes. The results are summarized as follows :

1) Sand dunes orerlie the $A$ horizon of soil formed at the uppermost part of terrace gravel beds along the outer margins of the second terrace plains of which the altitude is about $50-60 \mathrm{~m}$, the third terrace plains $(30-40 \mathrm{~m})$ and the fourth terrace plains $(5-10 \mathrm{~m})$. The geomorphic features of the sand dunes situated on the older (higher) terraces are not so typical as those situated on the younger (lower) terraces, although on the first terrace, there ts no sand dune. (Fig. 1 and Photos. 1-5).

2) The distribution of the sand dunes in this region is conditioned dy the exposure of the coast against the prevailing winds, and they are distributed on the coast of the direction from NE to SW facing winds from WNW in winter. (Fig. 1 and Tab. 1)

3) Moreover, the formation of the sand dunes is controlled by the amount of sand supply, which is conditioned by the nature of bed rock of the coast. In this region, the distribution of the sand dunes is limited to the area composed of Tertiary sedimentary rocks which are easily decomposed into a large amount of sands. But, in the coast to the south of Fukaura, is composed of volcanic rocks which are more resistant to weathering than the former, neither beach nor sand dune can be formed. (Fig. 1)

4) The sand dunes are usually composed of well sorted medium or fine sands (smaller, than $1 \mathrm{~mm}$ in diameter), and the grain size of the older sand dunes is somewhat smaller than that of the younger ones (Tab. 2). It seems to be a result of subaerial weathering after the formation of the sand dunes. Because such a thendency corresponds to modificatin of the geomorphic features of the sand dunes.

5) The sand dunes modify the terrace topography. They give the terrace plains small reliefs. The terrace scraps facing the prevailing wind of winter are covered by sands, and their slopes are very gentle. On the other hand, the terrace scarps free from sand dunes preserve their original steep slopes (Tab. 3).

21）渡辺 光：前揭 3) 